DOI: 10.36340/2071-6818-2020-16-4-10-18

The journal traditionally opens with an academic interview. In this issue, we present Dietrich Brauer, Archbishop of the Evangelical-Lutheran Church of Russia, member of the Council for Interaction with Religious Associations under the President of the Russian Federation, chevalier of the Order of Merit of the Federal Republic of Germany, who kindly agreed to answer questions from Maria Burganova, the Editor in chief of The Burganov House. The Space of Culture journal. 


\section{INTERVIEW WITH DIETRICH BRAUER, ARCHBISHOP OF THE EVANGELICAL-LUTHERAN CHURCH OF RUSSIA}

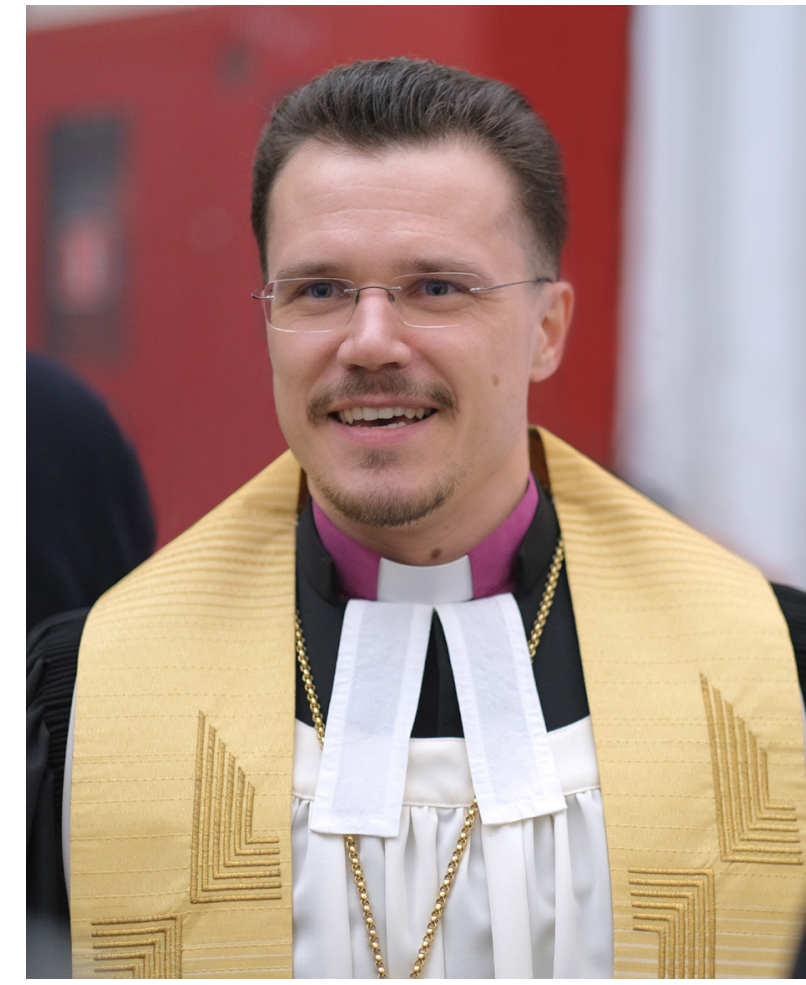

Dietrich Brauer, Archbishop of the Evangelical-Lutheran Church of Russia

solution to this problem united representatives of different countries and nationalities, of confessional and political preferences.

Institutionally, our Church is not connected with Germany. From the very first days, Lutherans in Russia have perceived themselves as an integral part of their new homeland with all the ensuing consequences. For centuries, Russian Lutherans have been directly participating in Russia's formation as a European and world power. Without giving up their faith, they have remained faithful to their country, glorifying it in the scientific, military, and cultural spheres. As part of the state's elite, holding high leadership positions and forming European dynastic ties, Lutherans will make an essential contribution to strengthening European self-awareness and realization of their shared responsibility for sustainable, peaceful development on the continent.

After the catastrophes of the $20^{\text {th }}$ century, much has to be rethought. Our church was literally 


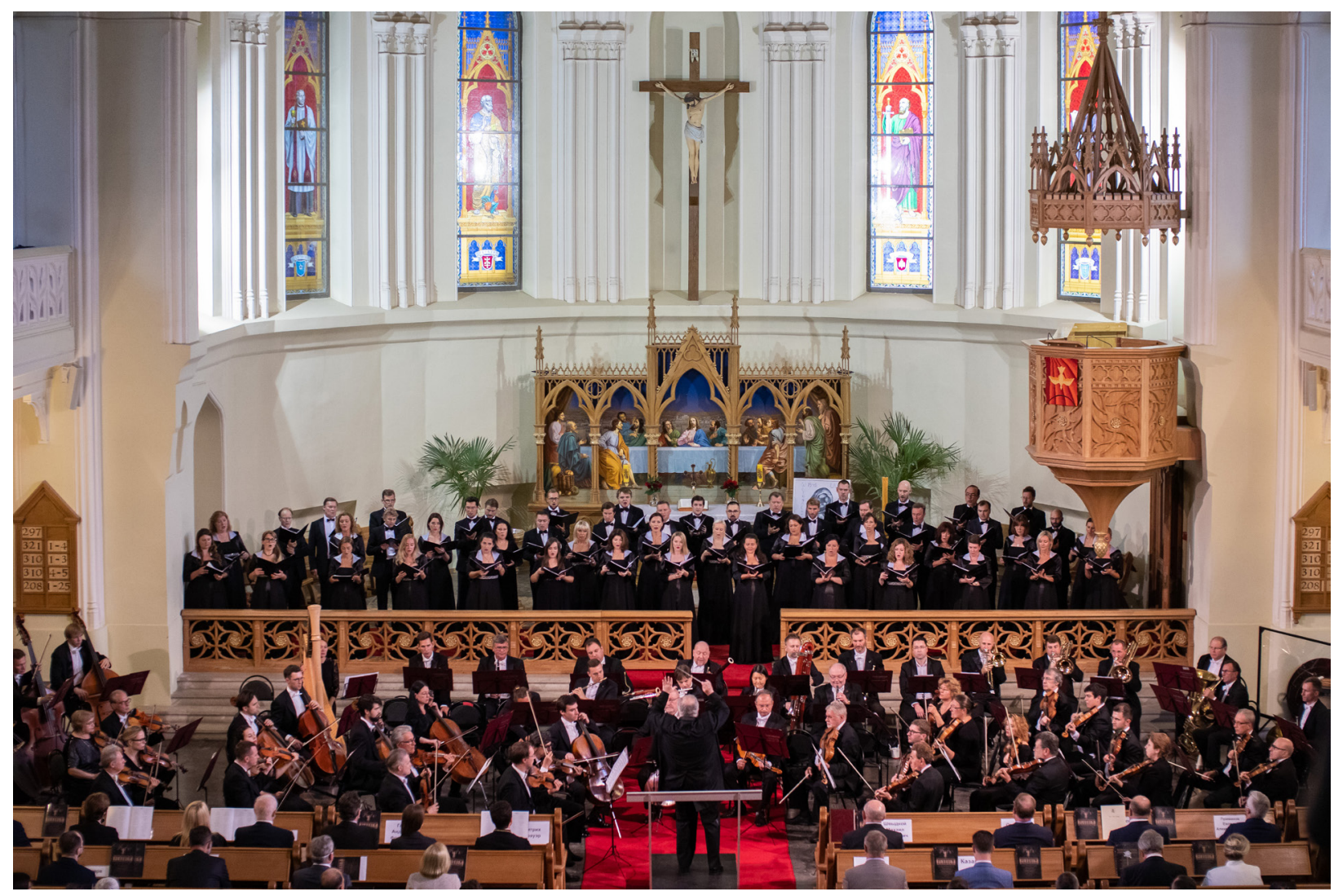

The Lutheran Church of Saint Peter and Saint Paul in Moscow

reborn from nothing. After all the persecution and repression, the faith has remained alive, and the legacy of Russian Lutheranism is in demand by society. For many, our church is the bearer of Western European Christian culture. Moreover, to a greater extent than in the case of the Roman Catholic Church, this culture is perceived as its own. After all, Lutheran spiritual centers are not located in Rome but in the country where church communities are located. The choice of values, ethical attitudes, creative self-expression, and professional responsibility are not so much formed by the power of the church's authority as they are based on inner Christian freedom. The church is perceived as a living community of people united by one Christian faith and realizing this faith both in the church at the service and in everyday life. We are aware of our Christianity in real life, full of contradictions and challenges. Each does this according to his or her abilities and vocation.

I find that President Steinmeier's arrival and his active participation in the act of returning the Cathedral of Saints Peter and Paul serve as significant evidence of what role the church can play today. The church is, first of all, people. The main reason for the head of Germany's visit was the desire to share the joy with his fellow believers and congratulate them on the $500^{\text {th }}$ anniversary of the Reformation. In his welcoming speech in the cathedral, he did not hide that participation in this event in Moscow was his inner motivation as a Christian. His words that this cathedral can become a place to meet and socialize for our peoples are also remembered. And this is what it is like. Today the cathedral is again filled with life. These are far from only church services. It is a multi-faceted ministry dedicated to building bridges for dialogue. It is not about the degree of religiosity and the desire to convert to their faith. It is primarily about creating a space for a free, open, sincere dialogue and spiritual diplomacy.

M.B.: Contemporary cultural space is multi-vector and multicultural. Do you consider it necessary for the church to participate in the modern artistic process? Previously, the church was the primary customer and censor of artistic works. Today it is an observer. Is it so? 



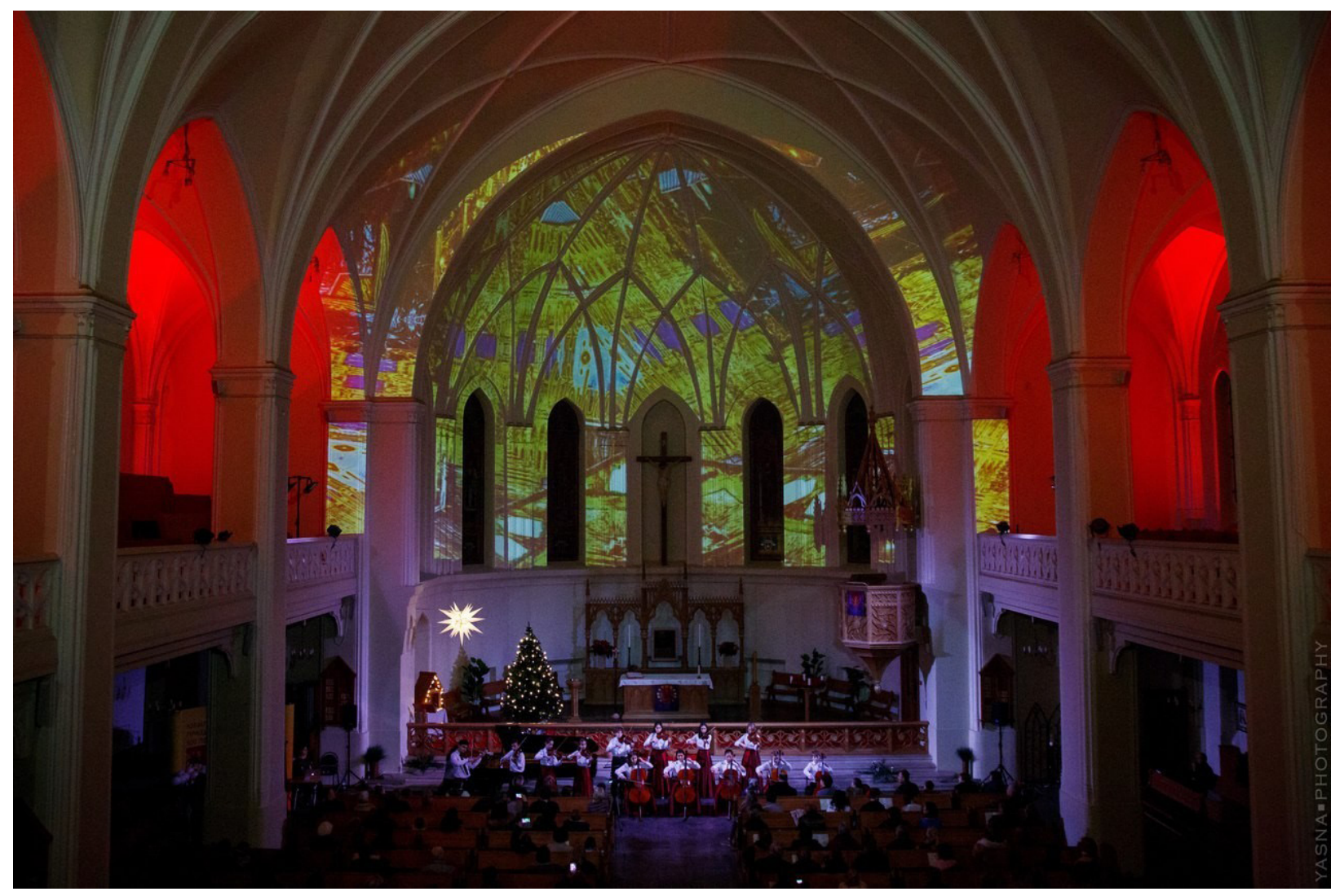

The Lutheran Church of Saint Peter and Saint Paul in Moscow

D.B.: I dare to hope that it is not. Our church does not perceive itself as a strict censor. However, without a doubt, art should be appropriate in the church, and the meanings conveyed by it should be correlated with the evangelical values. Today, many Lutheran churches have become venues for the most progressive artistic ideas. Here are just a few examples. In the catacombs of the Church of Saint Peter and Saint Paul (Petrikirche) on Nevsky Prospect, a permanent exhibition of paintings by Meta Lemba is located, and exhibitions of contemporary painting are regularly held. In 2017, the altar diptych of the famous Latvian artist, Daiga Pilsuma, was installed in the Church of Peter and Paul in Yaroslavl. The Omsk Resurrection Church is decorated with a triptych by Siberian artist Sergei Alexandrov. As for music, for example, Hindemith and Pärt sound in our churches in addition to such classical Lutheran composers as Bach, Brahms, Mendelssohn. Concerts, which are accompanied by artistic projections, creating the effect of the synergy of sound and image, have gained tremendous popularity.

M.B.: What role, didactic or artistic, does art play in the church? What are the cultural projects of the Evangelical Lutheran Church of Russia?
D.B.: The didactic and artistic functions of Christian art are interrelated. After all, painting, music, and architecture in the church ensure that people praise the Creator. Art in the church is an illustration of the gospel. These are images of the Good News, which serve to be imprinted in hearts and transform them. For example, the famous Lutheran chorales are sung not only in the church on Sundays. They are sung on weekdays, turning life into a hymn of praise.

Our church's cultural projects are part of its ministry. The themes of Sunday sermons in the Cathedral in Moscow are continued, for example, by cantatas from the cycle All Bach's Cantatas, the fourth season of which was opened this fall. Organ preludes to the chorales mentioned above are performed in the author's cycle by Alexander Fiseysky. Christmas concerts and fairs organized jointly with the German Embassy are traditional for us.

The Requiem commemoration action on September 2 was an important event in celebrating the $75^{\text {th }}$ anniversary of the victory in the Great Patriotic War. It included the presentation of a book of letters from Dietrich Bonhoeffer's prison Resistance and Submission in Russian, 
the consecration of a copy of the Madonna of Stalingrad by Kurt Reuber, the opening of the exhibition "Christian Martyrs - Victims of Nazism" and the performance of Johannes Brahms's German Requiem. President Putin and Chancellor Merkel sent greetings to the participants of the action.

M.B.: It is evident that creative and scientific thought cannot be contained. How do you assess modern scientific achievements, including research on artificial intelligence?

D.B.: As technology advances in the field of artificial intelligence, we increasingly yearn for simple tactile sensations when turning the pages of an old book, the smells of museums, the energy of the theater, live communication, and genuine emotions. Although the intention of any invention was initially, obviously, to make life easier for a person. And I must say that much in the modern world has become more accessible and more convenient. Yet some things are too important to be light and comfortable. Therefore, they need us completely, referring to our inner world. After all, it is here, in the soul, that our true self is hidden. Angels and demons are here. Love and hate are here. The acutely experienced dialectic of the soul is not an exact science and therefore is free for the poetic word, movement of the brush, and melody.

Today, artificial intelligence can practically replace humans. It is more efficient, reliable, and more uncomplicated. And it is scary. After all, a person can be lost in this way. Only a functional shell can remain. However, we can be grateful for such a development. After all, it pushes us to a new search to answer the question: what is a person? What makes us different from a car? What makes a person human? Here the dialogue of the soul with the Creator begins. The creative soul always strives for truth, for eternity, for God. It will not have peace until it finds the language that can express the inexpressible, extend the limits of the permissible, and overcome the boundaries of the restricted. In self-discovery, a kinship is revealed between theology, science, and culture. 
DOI: $10.36340 / 2071-6818-2020-16-4-10-18$

Традиционно наш журнал открывает академическое интервью. В этом номере мы представляем Дитриха Брауэра, архиепископа Евангелическо-лютеранской церкви в России, члена Совета по взаимодействию с религиозными объединениями при Президенте Российской Федерации, кавалера Ордена Командорский крест «За заслуги перед Федеративной Республикой Германия», который любезно согласился ответить на вопросы главного редактора журнала “Дом Бурганова. Пространство культуры» Марии Александровны Бургановой. 


\section{ИНТЕРВЬЮ С АРХИЕПИСКОПОМ ЕВАНГЕЛИЧЕСКО- ЛЮТЕРАНСКОЙ ЦЕРКВИ В РОССИИ ДИТРИХОМ БРАУЭРОМ}

Мария А. Бурганова: Кафедральный собор Святых апостолов Петра и Павла - главная лютеранская черковь России. В символической черемонии передачи храма в собственность Евангелическо-Лютеранской черкви России в 2017 году принял участие президент ФРГ Франк-Вальтер Штайнмайер. Полагаете ли Вы, что этот факт свидетельствует о важной роли ЕвангелическоЛютеранской церкви России в создании благоприятного диалогового пространства России и Германии?

Дитрих Брауэр: Торжественный акт передачи ключей от храма ознаменовал собой завершение длительного процесса возвращения кафедрального собора свв. Петра и Павла в церковную собственность. Не вдаваясь во все подробности этого сложного процесса, хотел бы подчеркнуть главное. Для того, чтобы благое дело восстановления исторической справедливости в отношении лютеран России увенчалось успехом, необходима была консолидация различных сторон. Нужно было, чтобы участники процесса и все те, от кого зависело принятие положительных решений, понимали значимость происходящего. Отрадно, что для решения этой задачи сплотились представители разных стран и национальностей, конфессиональных и политических предпочтений.

Институционально наша Церковь не связана с Германией. С самых первых дней лютеране в России воспринимают себя как неотъемлемую часть своей новой Родины со всеми вытекающими из этого последствиями. На протяжении столетий отечественные лютеране будут непосредственно участвовать в формировании России как европейской и мировой державы. Не отказываясь от своей веры, они оставались верными своей стране, прославляя её в научной, военной, культурной сферах. Входя в элиту государства, занимая высокие руководящие посты и формируя европейские династические связи, лютеране внесут важный вклад в укрепление европейского самосознания и осознание общей ответственности за устойчивое мирное развитие на континенте.

После катастроф XX века многое приходится осмыслять заново. Наша Церковь возродилась буквально из небытия. После всех гонений и репрессий вера осталась живой, а наследие российского лютеранства востребованным обществом. Для многих наша Церковь - это носитель западноевропейской христианской культуры. И эта культура в большей степени, чем в случае с римско-католической церковью, воспринимается как своя. Ведь лютеранские духовные центры находится не в Риме, а в стране нахождения церковных общин. А ценностный выбор, этические установки, творческое самовыражение, профессиональная ответственность формируются не столько силой авторитета церкви, сколько исходят из внутренней христианской свободы. Церковь же воспринимается как живое сообщество людей, объединённых одной христианской верой и реализующих эту веру как в храме на богослужении, так и в обыденной жизни. Именно здесь, в реальной жизни, полной противоречий и вызовов, мы и даем отчёт в своем христианстве. Делает это каждый соответственно своим дарам и своему призванию.

Приезд президента Штайнмайера и его деятельное участие в акте возвращения Кафедрального собора свв. Петра и Павла мне представляется очень важным свидетельством того, какую роль сегодня может играть церковь. Церковь - это прежде всего люди. Главным поводом для приезда главы Германии стало желание разделить радость со своими единоверцами и поздравить с 500-летним юбилеем Реформации. В своей приветственной речи в соборе он не скрывал, что участие в этом событии в Москве - это его внутреннее побуждение как христианина. В памяти остались и его слова о том, что этот собор может стать местом встречи и общения для наших народов. Так оно и происходит. Сегодня собор вновь наполнен богатой жизнью. И это далеко не только богослужения. Это многогранное служение, поставленное на то, чтобы строить мосты для диалога. При этом речь не идёт о степени религиозности и стремлении обратить в свою веру. Речь в первую очередь идёт о создании пространства для свободного, открытого, искреннего диалога и духовной дипломатии.

М.Б.: Современное культурное пространство многовекторное и мультикультурное. Считаете ли Вы необходимым участие черкви в современном художественном процессе? Раньше церковь была 
главным заказчиком и чензором художественных произведений. Сегодня она на позиции наблюдателя. Так ли это?

Д.Б.: Смею надеяться, что это не так. Наша церковь не воспринимает себя в роли строгого цензора. Но без сомнения, искусство должно быть по форме уместным в храме, а сообщаемые им смыслы соотноситься с евангельскими ценностями. Сегодня многие лютеранские храмы стали площадками для самых передовых художественных идей. Приведу лишь несколько примеров. В катакомбах церкви св. Петра (Петрикирхе) на Невском проспекте размещена постоянная экспозиция картин Мета Лемба и регулярно проводятся выставки современной живописи. В 2017 году в Петропавловской кирхе г. Ярославля был установлен алтарный диптих известной латвийской художницы Дайги Пилсумы. Омскую Воскресенскую церковь украшает триптих сибирского художника Сергея Александрова. Что же касается музыки, то, помимо таких классических лютеранских композиторов, как Бах, Брамс, Мендельсон, в наших храмах звучат, например, Хиндемит и Пярт. Большую популярность приобрели концерты, которые сопровождаются художественными проекциями, создавая эффект синергии звука и образа.

М.Б.: Какую роль играет искусство в храме - дидактическую или художественную? Каковы культурные проекты Евангелическо-Лютеранской церкви России?

Д.Б.: Дидактическая и художественная функции христианского искусства взаимосвязаны. Ведь и живопись, и музыка, и архитектура в храме служат тому, чтобы люди возносили хвалу Творцу. Искусство в храме - это иллюстрации к Евангелию. Это образы Благой вести, которые должны запечатлеться в сердцах и преображать их. Так, например, знаменитые лютеранские хоралы поют не только в храме в воскресенье. Они поются и в будни, превращая жизнь в хвалебный гимн.

Культурные проекты нашей церкви - это часть её служения. Темы воскресных проповедей в Кафедральном соборе в Москве продолжают, например, кантаты из цикла «Все кантаты Баха», IV сезон которого был открыт этой осенью. Органные прелюдии к упомянутым выше хоралам звучат в авторском цикле Александра Фисейского. Традиционными для нас являются рождественские концерты и ярмарки, организуемые совместно с Посольством Германии.

Важным событием в рамках празднования 75-летнего юбилея Победы в Великой Отечественной войне стало проведение 2 сентября акции памяти «Реквием». Она включала в себя презентацию книги писем из тюрьмы Дитриха Бонхеффера «Сопротивление и покорность» на русском языке, освящение копии «Сталинградской мадонны» Курта Ройбера, открытие выставки «Христианские мученики - жертвы нацизма» и исполнение «Немецкого реквиема» Иоганнеса Брамса. Приветствия участникам акции направили президент Путин и канцлер Меркель.

М.Б.: Очевидно, что творческую и научную мысль невозможно сдержать. Как Вы оцениваете современные научные достижения, включая исследования искусственного интеллекта?

Д.Б.: По мере развития технологий в области искусственного интеллекта, мы всё больше тоскуем по простым тактильным ощущениям при перелистывании страниц старой книги, запахам музеев, энергетике театра, живому общению и подлинным эмоциям. Хотя замысел всякого изобретения изначально заключался, очевидно, в том, чтобы облегчить человеку жизнь. И нужно сказать, что многое в современном мире стало легче и удобнее. Всё же остаются вещи, которые слишком важны, чтобы быть лёгкими и удобными. Потому они требуют нас целиком и полностью, обращаясь к нашему внутреннему миру. Ведь именно здесь, в душе, сокрыто наше подлинное я. Здесь - ангелы и демоны. Здесь - любовь и ненависть. Остро переживаемая диалектика души - это не точная наука и потому свободна для поэтического слова, движения кисти и мелодии.

Искусственный интеллект сегодня может практически заменить человека. Он эффективней, надёжней и проще. И это пугает. Ведь человека таким образом можно и потерять. От него может остаться лишь функциональная оболочка. Но мь можем быть и благодарны за такое развитие. Ведь оно подталкивает нас к новому поиску ответа на вопрос: что есть человек? Что отличает его от машины? Что делает человека человеком? Здесь и начинается диалог души с Творцом. Творческая душа всегда стремится к истине, к вечности, к Богу. Ей не будет покоя, пока она не найдет тот язык, который сможет выразить невыразимое, раздвинуть рамки допустимого и преодолеть границы ограниченного. В поиске и обретении человеком самого себя обнаруживается родственная связь между богословием, наукой и культурой. 